
76 巻 761 号 $(2010-1)$

\title{
等身大ヒューマノイド型跳躍ロボット用のカ学エネルギー 蓄積式直動燃焼アクチュエータの開発*
}

\author{
石野 洋二郎*1, 齋木 悠*1, 柴 田 遼 平*2 \\ 大澤 明日菜*3, 前 田一 樹*3, 大岩 紀 生*1

\section{Study on a Combustion Linear Actuator with a Mechanical Energy Accumulation for a Driving System of Full-Scale Jumping Robot} \\ Yojiro ISHINO**, Yu SAIKI, Ryohei SHIBATA, \\ Asuna OSAWA, Kazuki MAEDA and Norio OHIWA \\ ${ }^{* 4}$ Department of Mechanical Engineering, Nagoya Institute of Technology, \\ Gokiso-cho, Showa-ku, Nagoya-shi, Aichi, 466-8555 Japan

\begin{abstract}
In recent years, athletic humanoid robots have been popular, but the electrical motors equipped in their joints and heavy batteries do not allow them the more quick actions. Another type of actuators of light, compact and no-auxiliary, are required to bring them more quick motion. In this study, novel combustion linear actuator, which stores once a combustion driving force to springs as mechanical energy, was developed. First, a high-speed direct observations of the combustion behavior in a model constant volume chamber was carried out for a high performance combustion condition. Second, to verify the performance of the actuator for heavy load, an operational test of lifting was made. The test showed the successful lift performance for $27 \mathrm{~kg}$ mass par an unit. Prototype model of full-scale jumping robot, which is planed to be driven by the actuators, is also shown in this paper.
\end{abstract}

Key Words: Premixed Combustion, Flow Visualization, Actuator, Humanoid, High Speed Photography, Lenoir Cycle, Ignition, Jumping Robot

\section{1. 精言}

本研究では, 燃焼の利用範囲の拡大を目指して，等 身大ヒューマノイド型跳躍ロボットの跳躍駆動用に利 用可能な，ピストン・シリンダ式の燃焼アクチュエー タの開発を行う.ただし，通常，シリンダ内の橪焼ガ スは急速に冷却するため, 等身大ヒューマノイドロボ ットの跳躍時間を待たずして，シリンダ内燃焼ガス圧 力が低下してしまう，そこで，燃燒圧力を一旦バネに 力学エネルギーとして蓄積し, 燃焼ガスの泠却に無関 係にエネルギーを利用できる力学エネルギ一蓄積式直 動燃焼アクチュエータを考案し, 製作を行った ${ }^{(1,2)}$. 本報では，試作アクチュエータの性能試験として，は じめに，定容燃焼室内の可視化観察から火炎の燃焼挙

* 原稿受村 2009 年 6 月 22 日.

*1 正員, 名古屋工業大学大学院工学研究科(丞 466-8555 名古 屋市昭和区御器所町)

*2 学生員, 名古屋工業大学大学院工学研究科.

*3 名古屋工業大学大学院工学研究科.

E-mail : ishino@nitech.ac.jp

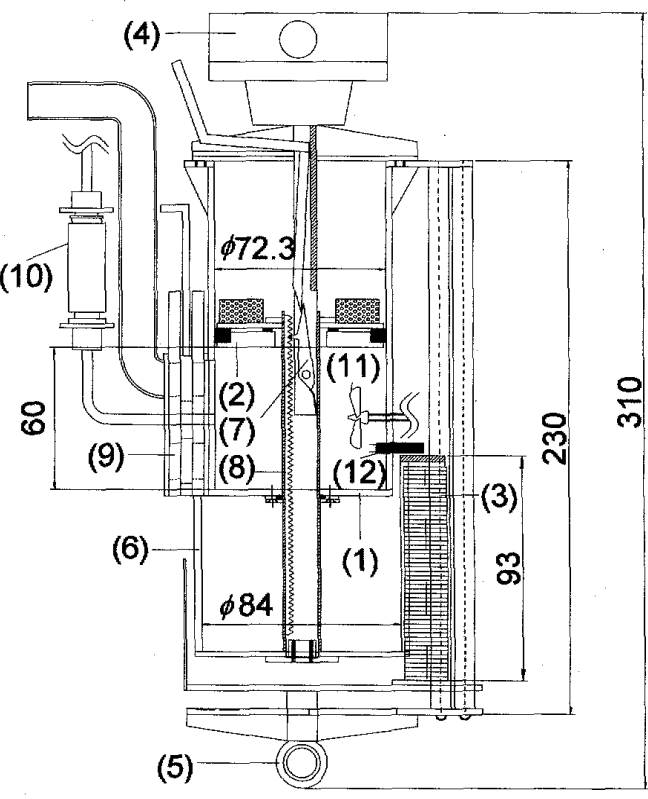

Fig. 1 The design of the proposed combustion linear actuator with mechanical energy accumulation 
動および定容容器での圧力変動を把握し，つぎに，重 量物の高速吊り上げ駆動実験を行った。

\section{2. 実験装置およひ実験方法}

\section{2:1 カ学エネルギ一蓄積式直動燃焼アクチュエー} タ 力学エネルギー蓄積式直動燃焼アクチュエータ の概要図を図1に, 重量物の吊り上げ実験装置の系統図 这2に，それぞれ示す.

供試アクチュエータは，主として，シリンダ (1)， ラチェット内蔵コンロッド付きピストン (2)，および バネ (3) から構成される. 本アクチュエータの人工筋 肉として使用に配慮し，燃焼室を中央にコンロッドが 貫通した特殊な形状とすることで，作動時に全長が収 縮する動作を実現した。アクチュエータの寸法は，等 身大モデルロボットの大腿部への収納を想定し，燃焼 室直径を72. $3 \mathrm{~mm}$, 燃焼室長さを $60 \mathrm{~mm}$, 全長を約 310 mmに設計した。燃焼室体積は234 mlである.

ここで, 概要図 (図1) を用いて作動原理の説明を行 う.まず, 燃焼時に生じる燃焼圧力によりピストン (2) が上昇し，同時にピストンに接続されたバネ固定スラ イダー (6) およびバネ上端が上昇を始める.このとき, 駆動出力下端（5）には図2のように重量物が接続され るため，バネ下端は僢間的には上昇せず，一時的に固 定された状態となる，一方，ピストンのストローク運 動によりバネ上端のみが上昇し, バネの伸長を力学工 ネルギーとして確保することができる.

ピストンおよびバネ上端は，コンロッドに内蔵され たラチェット機構（7）および（8）により最大ストロ 一ク位置で固定される. その後, 伸長したバネにより 重量物の高速吊り上げ駆動が実行される. 駆動終了後, ラチェット爪 (7) の解除によりピストンは初期位置に 戻る.

本アクチュエータにおらる燃焼サイクルは, 任意の タイミングでの駆動が要求されるため，無圧縮サイク ルであるルノアールサイクル(3) を用いた.

燃焼室筒内に予混合気を充填する方法を次に示す. 送風機により空気がスライドバルブ (9) を通して供給 される. 次にカセットボンべの燃料であるブタンをイ ンジェクター（10）により当量比に応じて量を調節し 供給する.これらをモータに接続されたファン (11) により攪拌し予混合気が形成される．混合気の着火に は, 点火電極（12）間に生じる点火火花を用い，点火 電極から火炎が伝播していくことでアクチュエータが 作動を開始する.

本燃焼室形状および燃焼条件から，最大熱効率を与 えるバネ定数は $15000 \mathrm{~N} / \mathrm{m}$ 程度と見積もられ (1)，この

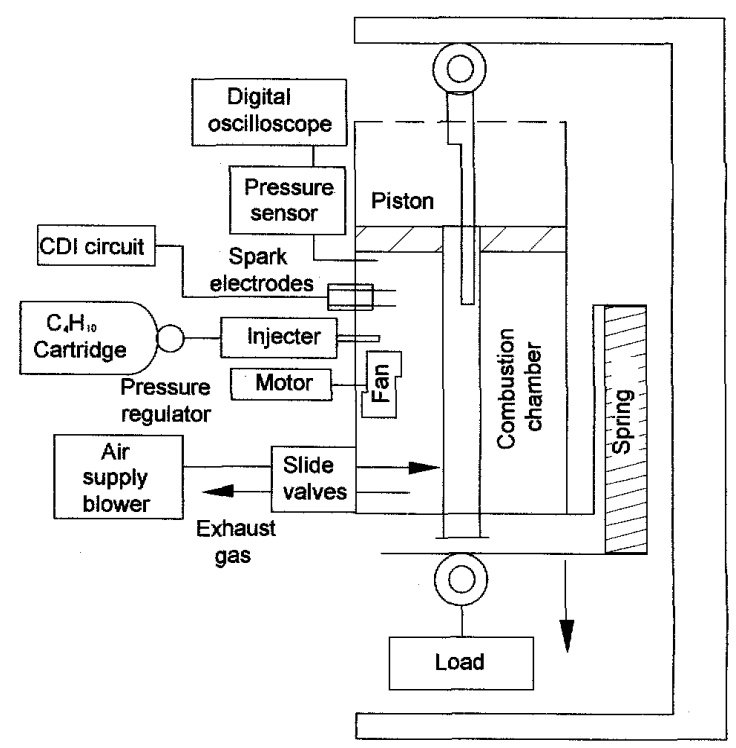

Fig. 2 Schematic of experimental apparatus

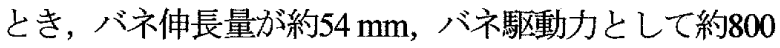
Nの力が得られる. そこで, 本アクチュエータのピス トン最大ストローク量を約50 mmに設定した. 前述の バネ定数を実現するため，本アクチュエータでは，バ 市定数 $2.1 \mathrm{~N} / \mathrm{mm}$ のバネを9本使用し，上記バネ定数に近 い合成バネ定数 $18900 \mathrm{~N} / \mathrm{m}$ 形成した。

$2 \cdot 2$ 燃焼室内可視化用定容燃焼器 本アクチュ エータの燃焼現象の可視化のための燃焼室内可視化用 定容燃焼器の概要図を図3に示す。この燃焼器は, 本ア クチュエータの作動直前の状態を模擬しており，イン ジェクター,ファン(羽寸法: 根元幅 $7 \mathrm{~mm}$, 最大幅 $10 \mathrm{~mm}$, 長さ $13 \mathrm{~mm}$. 羽枚数 : 3 枚. モ一タ一駆動. 実測回転数 $10300 \mathrm{rpm}$ ), 点火電極, 压力センサの配置もアクチュ エータと同様に設定されている. ただし，可視化のた めに，燃焼室底面は厚さ12 mmのガラ゙ス板となってい る.また，新気の吸入かつ燃焼ガスの掃気は，燃焼器 上面に設けた 2 力所のネジ穴（M12）を通して行う. この穴は然焼作動時には，ボルトで閉鎖する.

燃焼可視化実験の手順を説明する. 送風機からの空 気によりネジ穴を通して燃焼室内を掃気したのち，ボ ルトを甫いてネジ穴密閉する。つぎに，力セットボ ンベ燃料のブタンをインジェクターにより設定当量比 に応じた量だけ燃焼室内に供給し，ファンにより攪汼 し均一な予混合気を形成する.ファンの回転の停止後 $100 \mathrm{~ms}$ で花点火を行う。点火電極から火炎が伀播し ていく様子を高速度力メラにより撮影し，圧力センサ により压力を測定する. 

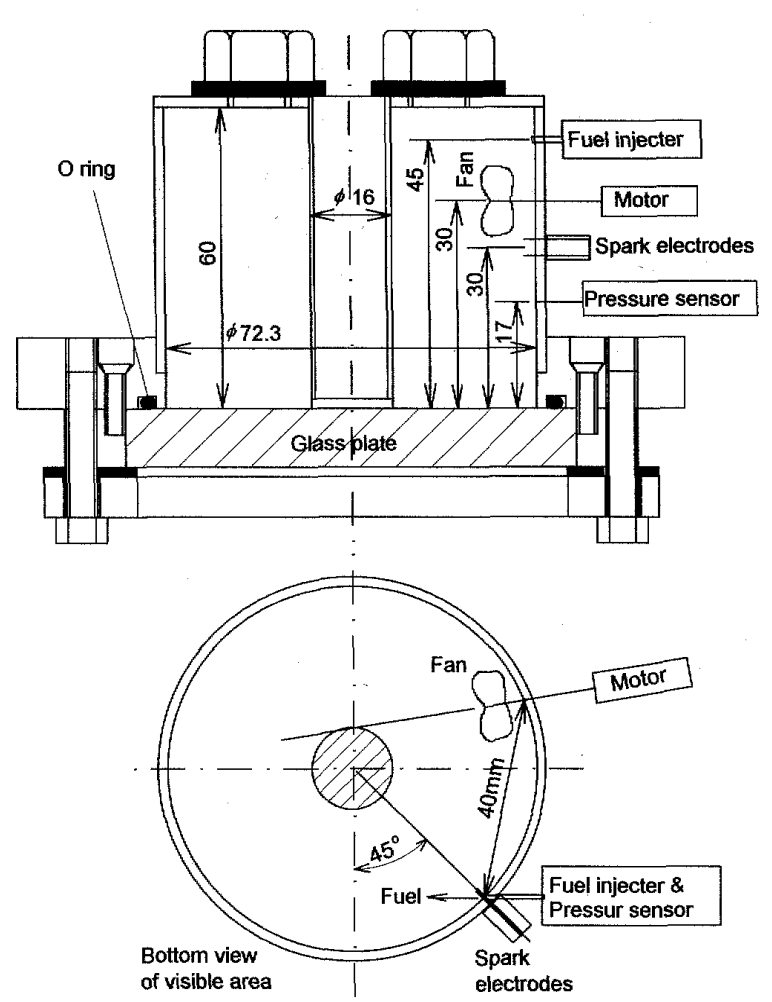

Fig. 3 Appearance of constant volume combustion chamber

$2 \cdot 3$ 等身大ヒューマノイド型跣羅ロボット＼cjkstart本 研究では, 等身大ヒューマノイドロボットの駆動に先 立ち、アクチュエータの作動状况を確認するため, バ 一ベル用ウェイト（質量 $27 \mathrm{~kg}$ ) の吊り上げ試験を主に 行うが，燃焼アクチュエータの設計目的を明確にする ため，駆動を計画している等身大ヒューマノイド型跳 躍ロボットについて記載する. 図4に等身大ヒューマ) イドロボットの初期姿勢の概観図（a）と系統図（b) を示す. 本ロボットは, 総質量約 $6.6 \mathrm{~kg}$, 直立時には全 長 約 $1400 \mathrm{~mm}$ であり, 跳躍前初期姿勢では全長 約 $1100 \mathrm{~mm}$ となる. 足首々滕関節間の距離は $400 \mathrm{~mm}(\mathrm{e}$ ： 下腿部), 膝と股関節間の距離は $410 \mathrm{~mm}(\mathrm{~h}$ : 大腿部)， 股関節と肩関節間の距離は $520 \mathrm{~mm}(\mathrm{j}:$ 胴)，そして足 の長さは $260 \mathrm{~mm}$ と設計されている. また（f)，（g），

(i) の部材は，本口ボットの跳躍動作を一自由度で行 うためのリンクで, それぞれ，約 $400 \mathrm{~mm}$, 約 $400 \mathrm{~mm}$, 約 $600 \mathrm{~mm}$ に設定されている.

次に図4の系統図を用いて作動原理の説明を行う.本 アクチュエータ（a：大腿直筋に相当）の駆動出力上端 を大腿部（b）に，駆動出力下端を下腿部 (c) に，そ れぞれ接続する. そしてアクチュエータを作動させる と駆動出力下端には等身大ヒニーマノイドロボットに よる負荷がかかっているため，バネ下端は急激には移 動せず，ピストンストロークによるエネルギーがバネ

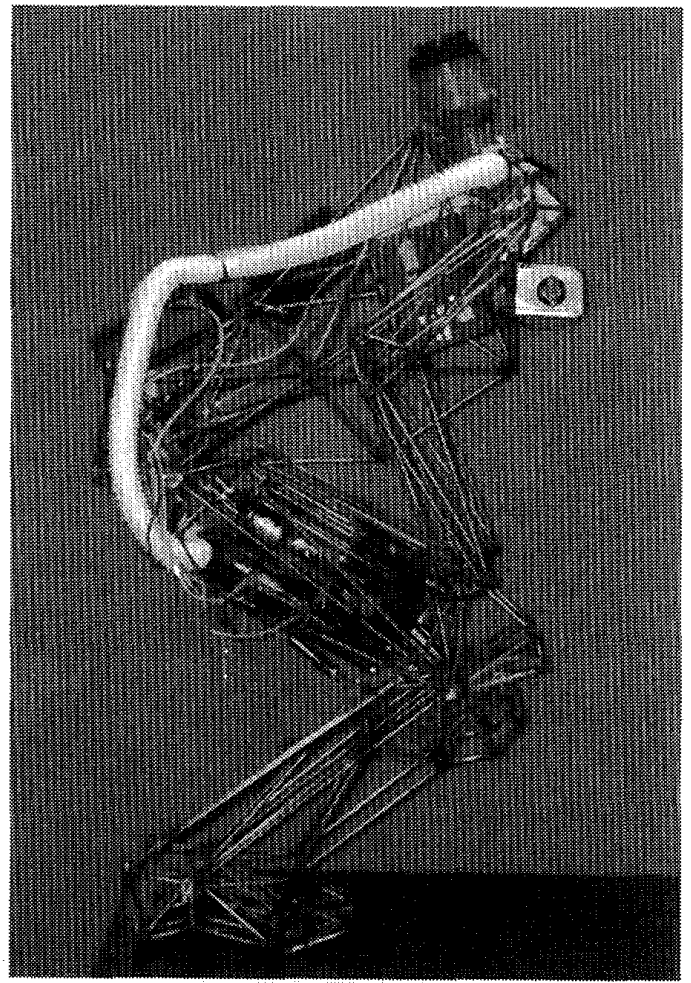

(a)

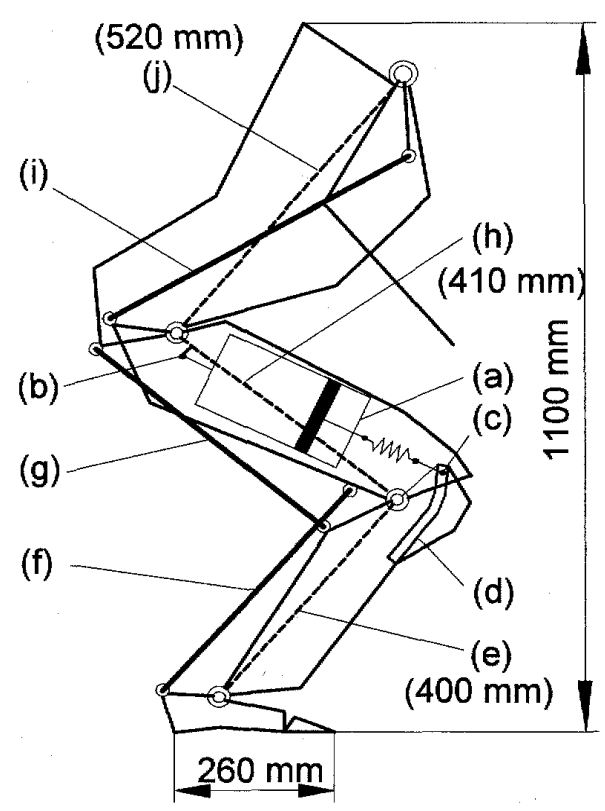

(b)

Fig. 4 Appearance of the humanoid robot

の力学エネルギーとして蓄えられる.ここで, ピスト ンおよびバネ上端は，2.1節での説明のように，最大 ストローク位置で固定される. その後, バネの収縮運 動により駆動出力下端がピストン力向に引が，部材 


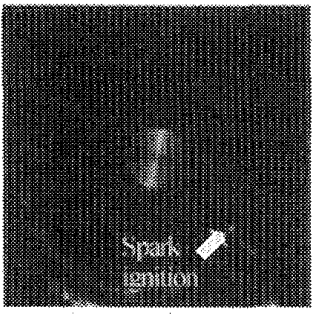

$0 \mathrm{~ms}$

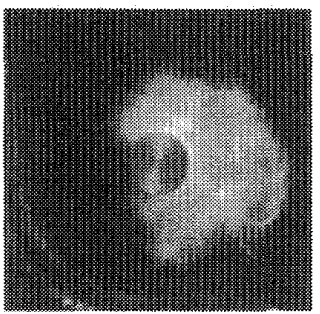

$8 \mathrm{~ms}$

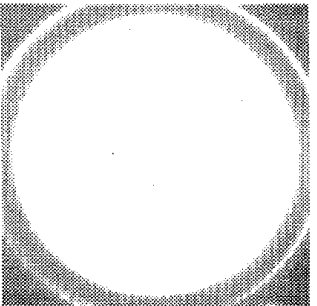

$16 \mathrm{~ms}$

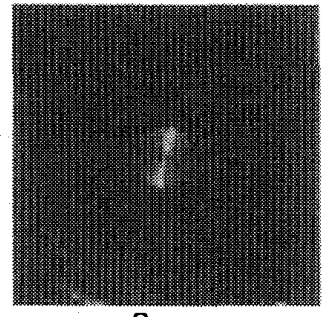

$2 \mathrm{~ms}$

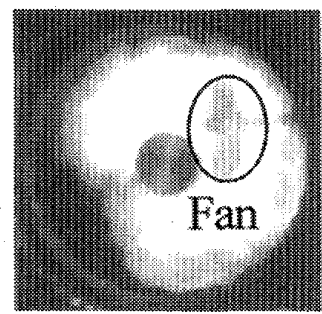

$10 \mathrm{~ms}$

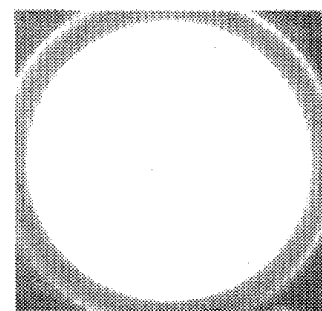

$18 \mathrm{~ms}$

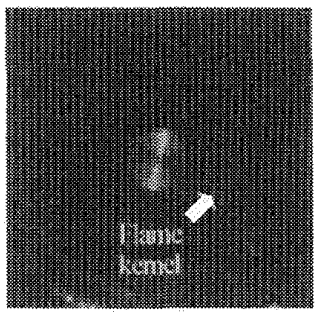

$4 \mathrm{~ms}$

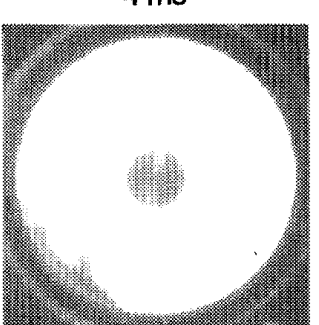

$12 \mathrm{~ms}$

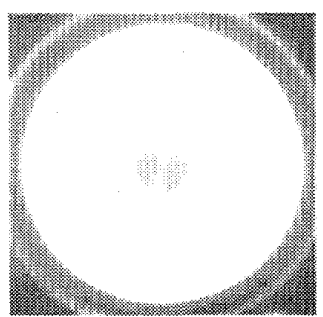

$20 \mathrm{~ms}$

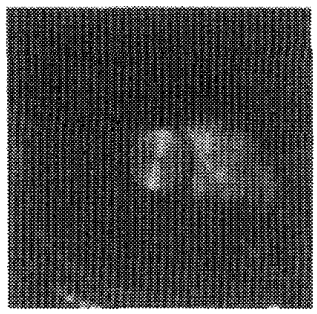

$6 \mathrm{~ms}$

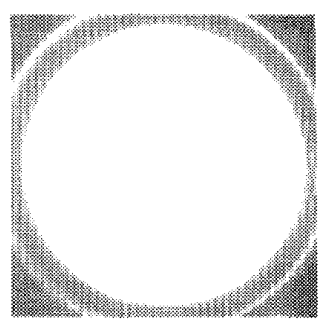

$14 \mathrm{~ms}$

Fig. 5 High speed photography of the constant volume combustion process

（d）（膝蓋骨に相当）を介して運動が下腿部に伝わる. 下腿部にはヒラメ筋および腓腹筋に相当する一対の準 平行リンク (e)-(f) を設けているため, 収縮作動による 膝下の運動は1自由度となる.また,この膝下の連動は， 平行リンク $(\mathrm{g})-(\mathrm{h})$ (大腿二頭筋おょよ゙半腱様筋に相 当）によって股下の運動として伝わり，これらの力の 伝達によりアクチュエータの収縮連動が下肢全体の上 昇運動となり, 跳躍作動に至る. また, 股下の跳躍作 動は（i）のリンクにより上体部の腕の振り上げ連動に 連動寸るため, アクチュエータの収縮運動による本口 ボットの跳躍動作は全体の系で1自由度として行われ る. 駆動終了後, ラチェットの解除によりピストンは 初期位置に戻る。

\section{3. 桔果および考察}

\section{3 - 1 定容燃焼器による可視化実験 定容然焼器} を用い,ファンによる混合気 (当量比1.0) 攪拌後 $100 \mathrm{~ms}$ で点火し燃焼状態の可視化撮影を行なった. 図5に，高 速度力メラにより撮影した可視化画像, 図6に圧力波形 を示す. 図5から, 燃燒室内での火炎伝播が確認される. すなおち，図5において右下領域 (0ms 矢印) に存在 する点火電極により点火された火炎核 (4ms 矢印) が, $6 \mathrm{~ms}$ およひ8 msにおいて，中心のコンロッドを取り巻 くように半時計方向に広がる様子が分かる.これは点

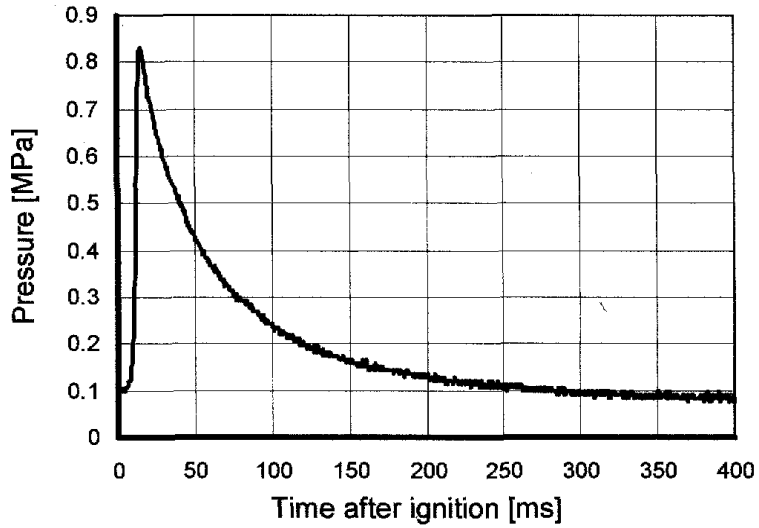

Fig. 6 Pressure variation in a constant volume combustion chamber

火後 $10 \mathrm{~ms}$ の図に現れているファンにより誘起される スワール流による伝播形態である．また，10 m/s程度 の高速な火炎伝播速度が得られているが，これは，燃 焼ガスの体積膨張，ならびに，ファンによって発生す る乱流に起因する.

燃焼室内圧力（図6）については，火炎輝度の増加率 が著しい点火後10 13 msにおいて圧力上昇率が最大と なり，点火後 $15 \mathrm{~ms}$ に最大压力が記録されている.ただ し, 点火後 $15 \mathrm{~ms}$ 以降, 壁面への冷却損失により急速に 圧力が低下しており，このことは，本提案アクチォエ 


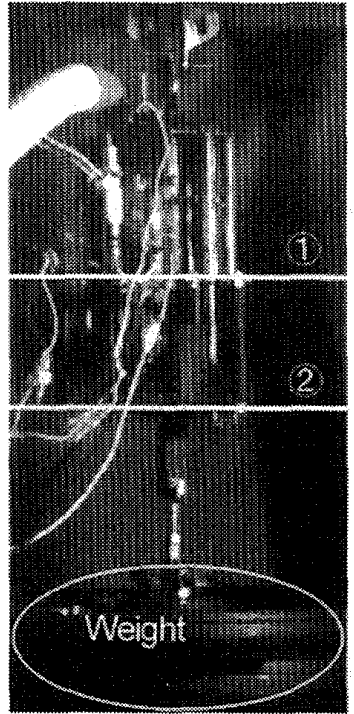

(a) $0 \mathrm{~ms}$

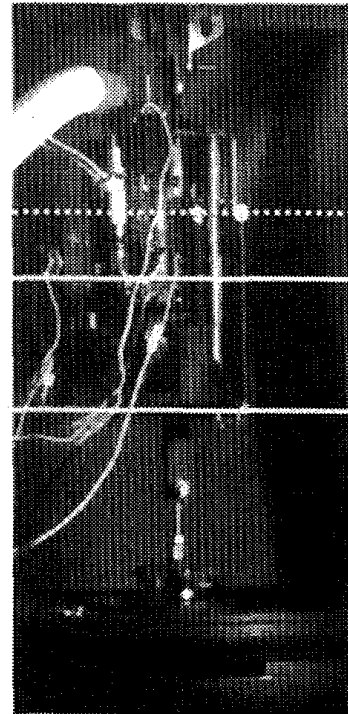

(b) $25 \mathrm{~ms}$

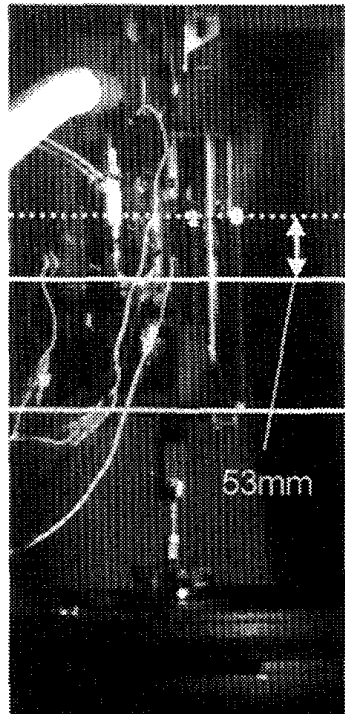

(c) $30 \mathrm{~ms}$

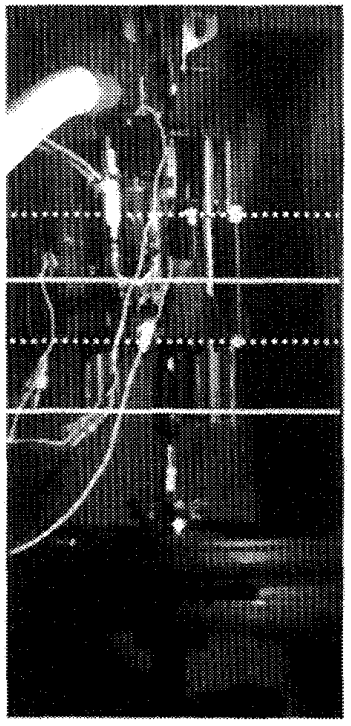

(d) $84 \mathrm{~ms}$

Fig. 7 High speed photography of the operation of the actuator with heavy loading

一タのような力学エネルギー蓄積式ではない通常のピ ストン駆動系においては，駆動対象に高速動作を望め ない場合には，泠却により駆動力が急速に低下するこ とを意味している.

3-2 アクチュエータ単体の性能実験 当量比1.1, バネ定数 $18900 \mathrm{~N} / \mathrm{m}$ 条件にお讨るバーベル用ウェイ 卜（質量27 kg）の吊り上げ実験により，アクチュエー タの性能評価を行った. 図7に,アクチュエータの吊り 上げ作動行程の高速度力メラ撮影画像を示寸．表記時 刻は点火からの経過時間であり，画像に示した実線は (1)：バネ上端，(2)：バネ下端の初期位置を表し，破線 は各位置の時間変位を表している，また，駆動出力下 端には重量物が接続されている.ここで，燃焼室内の 圧力波形を図8に，撮影画像から計测したバネ上端，下 端の時間変位を図9に示寸．点火後, 燃焼室内の圧力は 急激に上昇し，約 $14 \mathrm{~ms}$ で最大圧力0.67 MPaに達するこ とが分かる．つぎに，バネの変位に着目すると，点火 後 $12 \mathrm{~ms}$ においてバネ上端の上昇が開始し，時刻 $25 \mathrm{~ms}$ で最大高さ55 mmに到達していることが分かる. バネ 上端は図7(b)のように最大高さ到達後，(c)のように 2 $\mathrm{mm}$ 程度の変位の低下が観察されるが, これはピストン が燃焼器上蓋に衝撃する際に緩衝材の反発作用により 押し屃された変位であり，それ以降ではバネ上端変位 は約53 mmで安定している.これにより，ピストン・ コンロッド内に設けたラチェット機構が正常に作用し たことが分かる。

一方，バネ下端は時刻 $26 \mathrm{~ms}$ 上昇を開始し，バネの

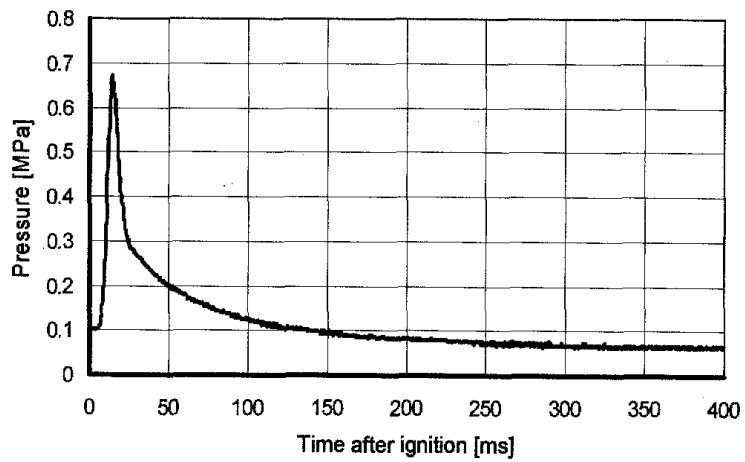

Fig. 8 Pressure variation in the combustion chamber of the actuator

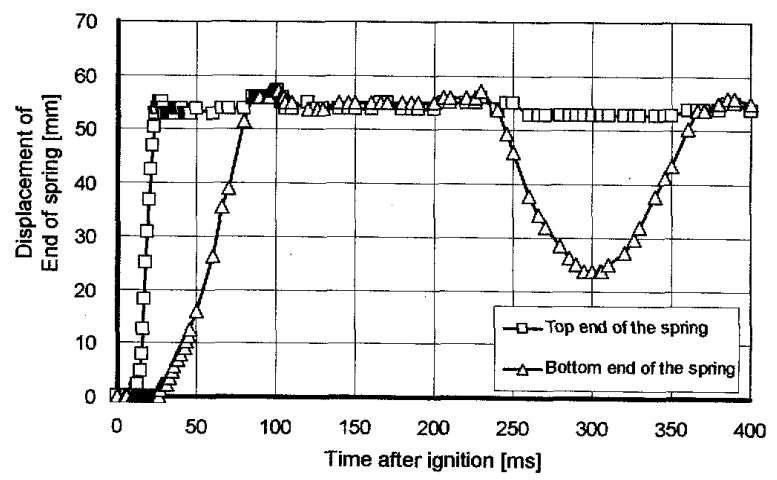

Fig. 9 Displacement of the ends of springs of the actuator 
伸長によるエネルギーでウェイトが50 ms程度の時間 で吊り上げられていることが分かる. $84 \mathrm{~ms}$ 以降に観察 されるバネ下端の大きな振幅は，重量物が起こすバネ 下端の振幅作動を捉えたものである.

また，本アクチュエータ作動時の圧力波形が，3，1 節での定容燃焼実験による圧力波形より，最大圧力以 降の立下りが速いことが確認される，とくに点火後25 $\mathrm{ms}$ まで圧力減少が著しいが，これはピストンの移動 による燃焼室体積の増大に起因するものである，点火 後 $25 \mathrm{~ms}$ でピストンが燃焼器上盍と衝突し, 急停止する ため, この時刻で燃焼室内圧力の低下速度が不連続を 示す. 本アクチュエータは, 高い燃焼室内圧力の時間 钼で主に力学エネルギーを蓄積するシステムであると と言えるが，ピストンが停止する時刻の圧力である0.2 $\mathrm{kPa}$ 程度のダージ圧力は使用できていない.この圧力を 利用するためには，ストロークをより長く変更すれば 良いが，伸長したバネ群の反力による圧力に抗する必 要があることに，注意を要する．以上のように，等身 大ロボットの駆動を想定したウェイトの吊り上げ駆動 には50 ms程度を要するのに対して，ピストンが約10 msという短時間で上昇することが確認され，力学エネ ルギー蓄積機構が有効に作用し，冷却による圧力低下 とはほぼ無関係に駆動力を利用することできるシステ ムが構築されたと言える.

\section{4. 結 言}

本研究では，等身大ヒューマノイド型跳躍ロボット の駆動を目的とし，力学エネルギ一蓄積式の燃焼直動 アクチュエータの設計・製作を行い，燃焼特性および 作動特性を把握した。本研究で得られた主な結果を以 下に記す。

（1）定容燃焼器による可視化燃焼害験より，アクチュ エータ内部でのファンの攪找によるスワール流を伴っ た燃焼状態加確認された。 また, 定容燃焼容器内の燃 焼では, 壁面冷却により燃焼後の容器内圧力が極めて 短時間で減少寸ることが分かり，本アクチュエータの 力学江ネルギー蓄積機能が，長時間の力の作用を必要 とする負荷には，必須であることが確認された。

（2）本アクチュエータは，27 kgの重量物を50 msの短時 間で約50 mm吊り上げる性能を有することが確認され た.

\section{文 献}

(1) Maeda, K., Shibata, R., Yamaguchi, T., Ishino, Y., and Ohiwa, N., Proceedings of the 57th Tokai Branch Regular Meeting of the Japan Society of Mechanical Engineers, No.083-1 (2008-3), pp.385-386.

(2) Ishino,Y., Maeda, K., Shibata, R., Osawa, A., and Ohiwa, N., Exhibition at Techno-Fair 2008 in Nagoya Instituteof Technology and Nagoya City University, (2008-11)

(3) Murayama, T., and Tunemoto, H., Engineering of Automobile Engine, (1999), p.17, Sankaid 